\title{
UDC 336.717
}

\section{AGRICULTURAL LENDING}

Drahan 0.O.

PhD in economics, associate professor

ORCID: 0000-0001-6431-8825

Shaliabin Ye.Yu.

undergraduate

Bila Tserkva National Agrarian University, Bila Tserkva, Soborna sq./8/1, 09117

\begin{abstract}
Regularities and tendencies of credit provision, estimation of influence of agrarian policy on a financial condition of the agricultural enterprises are investigated. Potential opportunities for agricultural producers to access bank loans are determined by the following factors - the cost of credit resources of commercial banks, the borrower's ability to repay the principal amount of debt and interest for its use, as well as fulfill the terms of the loan agreement. Financial instability and unprofitability of many agricultural enterprises, low creditworthiness of enterprises in the industry also hinder the development of credit relations, as banks want to see in borrowers only profitable customers. The main areas of stabilization of the mechanism of lending to agricultural enterprises should be the development of a set of measures by the state and the banking system aimed at developing a system of cooperation with the agricultural sector: increasing budget allocations, rational use of budget funds, attracting foreign loans, reducing interest rates for agriculture.
\end{abstract}

Key words: credit security, financial security, lending to agricultural enterprises, banking system, soft loan, government support, leasing lending.

\section{Introduction.}

The agro-industrial sector of Ukraine is the main component of agriculture and is a system-forming component of the national economy. The dependence of agroindustrial enterprises and, above all, agriculture on the financial and credit system has increased with the further development of market relations. Agribusiness is increasingly in need of financial investments that would be in circulation and aimed at the purchase of plant and animal protection products, seeds, fertilizers, fuel and the purchase of new equipment necessary for the renewal and technological modernization of production. In such conditions, only lending to agricultural enterprises can solve the problem associated with the specifics of agro-industrial production as a subject of lending.

Credit resources play a crucial role in the development of agriculture. This is due to the seasonal gap between investment and inflow of funds and the continuity of reproduction processes. The significant need for working capital in the absence of own funds turns credit into a significant source of financial resources and necessitates the search for ways to provide credit. However, obtaining loans for agricultural enterprises remains problematic.

Lending to agricultural enterprises by many banks has recently been considered an interesting and promising area. At the same time, the most popular financial products for agribusiness are: seasonal loans for growing crops, investment loans for the acquisition of agricultural assets, loans for agribusiness, as well as financial leasing of agricultural machinery. 


\section{The main text.}

The ingenious discovery of mankind is a loan through which the borrower is able to increase financial resources that can ensure a smooth production process. Credit in a modern market economy is a core and integral element of economic development. The positive impact of the loan, its impact on domestic businesses is assessed ambiguously. Some researchers of the theory of credit involve its involvement in the production process by the lack of material values necessary to ensure a smooth production process. Loan repayment, according to some researchers, leads to a deterioration in the financial condition of the borrower, and as a consequence - bankruptcy [1]. Other researchers argue that credit affects the timing of the production process and is the main impetus for the expanded reproduction and efficient operation of producers in modern conditions [1].

Studies show that credit is an inevitable attribute of agribusiness, as its attraction is not caused by the poverty of the borrower, and the objectivity of the production process and capital turnover due to the need for additional funds. Agrarian businesses are interested in the continuous development of production, creating all the conditions for expanded reproduction without "freezing" excess financial resources in their assets. Any production is the basis for the emergence of credit relations between entities. The production activity of agrarian business is characterized by a series of gradually implemented steps, which differ in sectoral features, among others.

With the help of borrowed funds, including loan, in accordance with preapproved business plans, an uninterrupted process of production of agricultural producers. That is why the definition of "credit" should be considered as an economic category, which is a certain type of social relations that effectively affects the movement of value.

Today, the role of credit and banking institutions in economic processes is especially relevant, which is why the study of credit theory is reflected in a significant number of scientific papers. In the process of evolution, scientists have conventionally divided the theory of credit into two interdependent theories naturalistic and capital-forming. The founders of naturalistic theory were David Ricardo, Adam Smith, John Mill, Ann Turbo, Karl Marx, Jean-Baptiste Say, Alfred Marshall, who argue that the economic basis for the development of credit relations is the process of production and capital turnover. That is why, in the study of the essence of the naturalistic theory of credit, the basis was the process of production, means of production and the cost of reproduction of working capital [2].

Researchers of the naturalistic theory of credit have noted that the money provided in credit, act as a technical means for redistribution of cost from one subject of credit relations to another, and banking institutions (profitable houses) act only as intermediaries accumulating temporarily free means, and in then provide them in the form of credit.

In contrast to the classics, Joseph Schumpeter in his research at the center of his theory brings the figure of the entrepreneur - an economic entity whose functions are different from the role of both capitalist and worker. Using such an institution as credit, it accumulates the factors of production and, having received them at its 
disposal, conducts innovative activities by implementing the achievements of technical progress, finds new needs, markets, forms of labor organization and more. As a result, for the revealed initiative the businessman receives profit, and the commodity producer - a push to development. The concept of the entrepreneur as the main figure of market relations underlies the interpretations of "capital", "profit", "interest" and "money" proposed by Josef Schumpeter [3].

It is worth noting that the naturalistic theory of credit has both advantages and contradictory ideas. The results of the study show that the advantage of this theory is to give priority to the production process of the aggregate product, and credit provides a continuous production process, which positively affects the financial performance of the borrower, as the mass of profit depends on interest on the loan [4].

The disadvantage of interpreting this theory is that:

- underestimated role and specific features of the loan;

- unexplored ability of borrowed funds to expand reproduction;

- the differences between loan and real capital are not fully defined;

- little attention is paid to the interdependence of interest rates and the ratio of loan capital to supply and demand, as well as the impact of market conditions [5, p. 9].

John Law and Henry McLeod are the founders of the capital-forming theory of credit. In their research, they note that the equivalent principles are laid down between credit and money, which play the role of capital, wealth, and act as a driving force for expanded reproduction of production. Banks are only the creators of credit and capital, which is why they should actively influence production, in particular through credit and the issuance of money. The erroneous approach of economists was that the size of the loan depends on the objective conditions of the economy, i.e. banks are able to prevent inflation, financial crises, etc. [4].

It is worth noting that naturalistic and capitalist theories have developed in parallel over a long evolutionary period. However, having opposite approaches to the nature of credit, in fact identical, because there is no doubt that savings through credit are transformed into real investment, ie credit performs a redistributive function in the economy and, at the same time, banking institutions - the function of capital formation. Nowadays, economic thought takes into account both positive and negative statements of both theories, which expands the possibilities of a thorough study of credit theory in accordance with modern business conditions.

A new vision of the theory of credit relations was found in the work of TuganBaranovsky M. in which economic cycles with real, production needs, namely, the periodicity of renewal of basic resources are substantiated. The action of the mechanism of the economic cycle in comparison with the operation of the steam engine. The role of steam in the cylinder is performed by the accumulated loan capital. In a steam engine, when the steam pressure acting on the piston causes it to move and push to the edge of the cylinder, the steam finds a way out and the piston returns to its place. In the manufacturing sector, the accumulated loan capital, having reached a certain rise, further moves, spending on elements of fixed resources. Under the full use of borrowed capital, the producer returns to the starting position, and 
again needs funds for reproduction [6, p. 89].

Examining the definition of "credit", it is worth justifying its impact on the agricultural sector, as its excessive involvement in production, both in theory and in practice, has long been considered one of the main causes of bankruptcy. Thus, in the research of Matthew Carey (1816) "Essays on Banking" considered the practical issues of trade depression. The research is based on the author's economic situation in the XIX century after the war. Then, the growth of industrial production prompted an increase in trade. Banks should have restrained the growth of trade operations, but on the contrary by promissory notes, encouraged their excessive spread. According to Carey M., the policy of banking institutions should be more adapted, and only then "industry, trade, labor would maintain a" moderate movement of its development "without striking ups and downs" [6].

Some scholars consider credit in a narrow sense, only from the issuing functions of the bank, ie by creating funds in the form of special funds for business lending. This theory is called stock. The essence of which is that the redistributive function of credit is not the main, and in the first place is the creation of a credit fund for economic turnover. The essence of the loan is considered as one of the simplest forms, in particular a loan agreement [7].

With the development of independent Ukraine, researchers have studied the theory of credit through the prism of the credit mechanism and the role of credit in terms of market relations. Modern financial science develops on the basis of the achievements of the directive economy, by preserving, developing and supplementing new categories, tools and research methods, opportunities for practical application in accordance with the challenges of a market economy, in need of further development by adapting the achievements of world economics.

Market conditions have posed new challenges for producers in the development of lending to agribusiness in terms of constant updating of methodological and methodological foundations of the study. Changing forms and types of credit risks, free pricing, the impact of credit policy on the efficiency and effectiveness of banks and borrowers, and many other problems require theoretical research and practical rethinking.

\section{Conclusions.}

The conducted research of credit relations testifies that the further development of the credit causes ambiguous changes in the organization of activity of agrarian business. The considered researches of scientists show that any economically unjustified directive intervention of the state in the activity of the market mechanism violates the action of market laws and reduces the efficiency of the economy. It should be noted that the establishment of effective credit relations of banks with borrowers is possible only if the theoretical justification of the loan, its role in the reproduction process and the introduction at the state level to ensure uninterrupted lending to agribusiness scientifically sound control into market mechanisms through the adoption of relevant regulations. legal provisions in the field of lending, insurance, taxation, budget policy, which are aimed at improving credit relations, support for banking institutions and the agricultural sector, which in turn will help the country out of the financial crisis. 


\section{References:}

1. On banks and banking: Law of Ukraine of December 7, 2000 № 2121-III. Legislation and regulations on banking. 2001. № 1. pp. 3-47

2. Bechko P.K., Gerasimova T.P. Bank lending to agricultural production: a monograph. Uman .: VOC "Vizavi", 2013. 189 p.

3. Gomza V.M. The current state of lending to agricultural enterprises: problems and ways to solve them. Scientific Bulletin of Kherson State University. Ser. : Economic sciences. 2014. Vol. 6 (2). pp. 137-141.

4. Rykun O.M. Cooperative development of small business in agricultural production. AgroWorld. 2009. № 1. pp. 31-34.

5. Aranchiy V.I. Credit in the system of financial support of investment development of agricultural enterprises / V.I. Aranchiy, O.P. Zorya, I.I. Petrenko. Bulletin of the Poltava State Agrarian Academy. 2011. № 4. pp. 120-244.

6. Information and analytical portal of the AIC of Ukraine. URL: https://agro.me.gov.ua

7. Financial sector statistics. URL: https: //bank.gov.ua/ua/statistic/sectorfinancial/data-sector-financial\#1ms.

8. Experts spoke about the impact of quarantine on the agricultural market in Ukraine. URL: http://agrobusiness.com.ua. 3. Reliable leverage: TOP-15 banks lending to the agricultural sector. URL: https://landlord.ua/reytingi/nadiyne-plechetop-15-bankiv-shho-kredituyutagrosektor.

9. Tsymbalyuk I., Rykovska L. Theoretical analysis of the essence and components of the definition of "agricultural sphere". Economic theory and history of economic thought. 2017. № 4. pp. 13-18.

Article sent: 03.09.2021

(C) Drahan O.O.

(C) Shaliabin Ye.Yu. 